\title{
Cord Blood Adipocytokines and Body Composition in Early Childhood: A Systematic Review and Meta-Analysis
}

\author{
Christos Bagias ${ }^{1,2}{ }^{D}$, Nithya Sukumar ${ }^{1,3} \mathbb{D}^{D}$, Yonas Weldeselassie ${ }^{1} \mathbb{D}$, Oyinlola Oyebode $^{1}$ and $^{-}$ \\ Ponnusamy Saravanan 1,3,*(D)
}

1 Division of Health Sciences, Department of Population Evidence and Technologies, Warwick Medical School, University of Warwick, Coventry CV7 7HL, UK; chrisba1983@yahoo.gr (C.B.); N.Sukumar@warwick.ac.uk (N.S.); y.weldeselassie@warwick.ac.uk (Y.W.); o.r.o.oyebode@warwick.ac.uk (O.O.)

2 Department of Endocrinology and Diabetes, University Hospital of Ioannina, 45500 Ioannina, Greece

3 Academic Department of Diabetes, Endocrinology and Metabolism, George Eliot Hospital NHS Trust, Nuneaton CV10 7DJ, UK

* Correspondence: p.saravanan@warwick.ac.uk

Citation: Bagias, C.; Sukumar, N.; Weldeselassie, Y.; Oyebode, O.; Saravanan, P. Cord Blood Adipocytokines and Body Composition in Early Childhood: A Systematic Review and Meta-Analysis. Int. J. Environ. Res. Public Health 2021, 18, 1897. https:// doi.org/10.3390/ijerph18041897

Academic Editor: Paul B. Tchounwou Received: 13 December 2020

Accepted: 12 February 2021

Published: 16 February 2021

Publisher's Note: MDPI stays neutral with regard to jurisdictional claims in published maps and institutional affiliations.

Copyright: (c) 2021 by the authors. Licensee MDPI, Basel, Switzerland. This article is an open access article distributed under the terms and conditions of the Creative Commons Attribution (CC BY) license (https:// creativecommons.org/licenses/by/ $4.0 /)$.

\begin{abstract}
Childhood obesity is a growing epidemic. Early identification of high-risk groups will allow for the development of prevention strategies. Cord blood adipocytokines have been previously examined as biomarkers predicting future obesity. We conducted a systematic review looking at the association between cord blood leptin and adiponectin with adiposity up to 5 years of age. A literature review was performed between January 1994 and August 2020 using two bibliographic databases (Medline/Pubmed and EMBASE) and was registered on PROSPERO (CRD42017069024). Studies using skinfold thickness and direct methods of assessing body composition in full term neonates were considered. Partial correlation and multiple regression models were used to present the results. Meta-analysis was performed, were possible, using a random effects model. Cochran's $Q$ test was used to assess heterogeneity and $\mathrm{I}^{2}$ statistics to calculate the percentage of variation across studies. The potential for publication bias was assessed using funnel plots. Data from 22 studies were retrieved and reviewed by two independent reviewers. Cord blood leptin was positively associated with adiposity at birth $(r=0.487 ; 95 \%$ CI: $0.444,0.531)$ but was inversely related to adiposity up to 3 years of age. The association was not sustained at 5 years. There was a weak positive association between adiponectin in cord blood and adiposity at birth $(r=0.201$; 95\% CI: 0.125 , 0.277). No correlation was found between cord blood adiponectin in young children, but data were limited. This review supports that cord blood leptin and adiponectin are associated with adiposity at birth. The results of this study provide insight into the role of adipocytokines at birth on future metabolic health and their potential use as risk stratification tools.
\end{abstract}

Keywords: cord blood leptin; cord blood adiponectin; adiposity

\section{Introduction}

Childhood obesity has reached epidemic levels and constitutes one of the greatest public health challenges of the 21st century. Globally, the number of infants and young children up to the age 5 years affected by obesity are expected to increase to 70 million by 2025 [1]. This is associated with both short and long-term adverse outcomes. Children with obesity are likely to become adults with increased risk of diabetes, cardiovascular disease, osteoporosis, and cancer [2-5]. The origin of obesity is multifactorial, primarily caused by an imbalance between energy intake and expenditure. Sedentary lifestyle, poor diet, genetics, and epigenetics are central in the development of this [6]. There is increasing evidence that events occurring in early life, even before birth, can cause obesity. During fetal life the body goes through critical periods of development with lasting or life-long effects and, therefore, the intrauterine environment may program long-term 
trajectories of adiposity and metabolic health [7]. Identification of high-risk groups can help in developing preventative strategies for reducing childhood obesity and adverse cardiometabolic disorders.

Adipose tissue in infancy is essential in ensuring adequate energy supply to the brain in a period of nutritional disruption and acts as a thermo-insulator (white adipose tissue) and thermo-regulator (brown adipose tissue) [8]. While it has a protective role against infections, intensive care unit admissions, and mortality [9,10], the recent evidence shows that the strongest predictors of adult obesity are large for gestational age (LGA) and obesity in preschool children. However, the optimal range of adiposity in children that defines "beneficial versus metabolically harmful" levels of fat mass is yet to be identified [11]. To address this, researchers proposed body composition growth charts as opposed to birth weight charts to improve the predictive ability of future obesity [12]. Others tried to use cord blood adipocytokines such as leptin and adiponectin as objective markers to predict future obesity, in contrast to adiposity measurements, which are subjective and prone to measurement errors.

Leptin is predominantly produced by adipocytes [13]. Placenta, muscle, bone marrow, and stomach are other sites of leptin secretion [14-17]. Leptin regulates body weight through negative feedback between fat mass and hypothalamic centers of satiety [18]. In addition, it also controls basal metabolic rate. When it is bound to leptin receptors, expressed by many tissues, the energy expenditure at the cellular level increases [19]. Maternal leptin does not cross the placenta due to its high molecular weight [20]. In addition to fetal adipose tissue, the placenta is a major producer of leptin during fetal life and a significant contributor to cord blood leptin levels, despite $98 \%$ of its production being secreted into maternal circulation.

Adiponectin is almost exclusively produced by adipose tissue in adults [21]. It plays an important role in glucose and lipid metabolism, is inversely related to leptin, and low levels are observed in obesity [22], type 2 diabetes, and metabolic syndrome in adults [23]. Cord blood adiponectin is not related to maternal concentrations [24] and is not shown to be derived from placental or maternal tissue [25-27]. Apart from adipose tissue, adiponectin mRNA is also found in other tissues (muscle, kidney, skin) during fetal life [28]. Whether cord blood adiponectin simply mirrors fetal adiposity or also acts as a growth factor remains to be established.

Published studies reporting the association between cord blood adipocytokines and adiposity at birth show inconclusive results. Most were cross-sectional and in small cohorts [29-42]. Thus far, there have only been three moderately sized longitudinal [43-45] studies examining the link between cord blood levels and adiposity in early childhood. It is difficult to draw firm conclusions from these studies due to the different ethnic groups sampled and different methods in assessing the body composition. The purpose of this systematic review was to summarize these studies to improve the power and to shed light on the role of cord blood leptin and adiponectin on adiposity at birth and in early childhood.

\section{Materials and Methods}

\subsection{Search Strategy and Study Selection}

Observational, cross-sectional, and longitudinal studies were examined. Studies of the offspring of healthy pregnant women and those with obesity were included. For studies involving participants with diabetes (type 1 or 2, gestational diabetes), data obtained only from control groups were used, as offspring of mothers with diabetes have higher leptin concentrations for a given fat mass [46,47]. Studies of full term neonates of different growth patterns - appropriate for gestational age (AGA), small for gestational age (SGA), LGAand ethnic origin were considered eligible. Studies examining neonates born preterm and/or with congenital abnormalities (chromosomal disease, respiratory distress syndrome, heart disease, and renal disease) were excluded. Randomized control trails were not included in the current systematic review. Due to the different criteria used to define SGA, LGA, and obesity across various populations, we accepted the authors' definition. 
Cord blood samples, measuring leptin and adiponectin, analyzed by enzyme-linked immunosorbent assay (ELISA) or radioimmunoassay (RIA) qualified for the meta-analysis. Leptin results were reported in $\mathrm{ng} / \mathrm{ml}$ and adiponectin in $\mu \mathrm{g} / \mathrm{ml}$. We included studies that assessed neonatal and childhood adiposity by air displacement plethysmography (ADP), dual energy $X$-ray absorptiometry (DXA), magnetic resonance imaging (MRI), and anthropometric measurements (skinfold thickness). Studies using only ponderal index as a measure of adiposity were excluded.

The review was registered on PROSPERO (CRD42017069024). Meta-analysis of observational studies in epidemiology (MOOSE) guidelines were followed for the study [48]. Since the review involved synthesis of published data, National Health Service (NHS) Research Ethics Committee approval was not required.

A literature search was performed between January 1994 (discovery of leptin gene) and August 2020. Two bibliographic databases were used to conduct the searches: Medline/Pubmed (National Library of Medicine and National Institute of Health) and EMBASE (The Excerpta Medica Database). The following keywords and medical subject headings (MeSH) were used: "leptin", "adiponectin", "fetal blood", "umbilical cord blood", "adiposity", "obesity", "body composition", "fetal growth", and "anthropometry". Search words were combined using Boolean operators (AND, OR). The search was limited further to those studies published in English and performed in humans from birth to 5 years of age. Reference lists from included studies were reviewed for further potentially eligible articles. If full-text online access was not available original journals were retrieved from the library services. Unpublished studies were not considered.

\subsection{Data Extraction}

Level one screening of search results (title and abstracts) was performed by two independent reviewers (CB and NS), using the inclusion and exclusion criteria provided. Level two screening of the full manuscripts was conducted by them independently (CB and NS) and any discrepancy was resolved by consulting a third reviewer (PS/OO). The PICO (Population, Intervention, Comparison, Outcome) framework was used to formulate the search strategy. For studies fulfilling the inclusion criteria, the independent reviewers extracted details onto standard data extraction templates. This included information about the type of study, location, and time of data collection, population, sample size, type of leptin and adiponectin assays, statistical methods, and technique to assess body composition. Any disagreement was resolved by discussion or by consulting a third reviewer.

\subsection{Statistical Analysis}

Partial correlation and multiple regression models were used to present the results. Studies were reported narratively, when correlation coefficient $(r)$ was unable to be extracted. Meta-analysis of correlations was performed using a random effects model because of the varying population characteristics and sample sizes. Cochran's $Q$ test was used to assess heterogeneity and $\mathrm{I}^{2}$ statistics to calculate the percentage of variation across studies that was due to heterogeneity rather than chance. As different methods of assessing adiposity were used (DXA, ADP, skinfold thickness), the test of moderators was applied. We included "method" in the random effects model to examine the effect on heterogeneity. The results showed that there was no evidence for heterogeneity between the type of adiposity measures (QM test for moderators, $p=0.50$ ). Hence in the final random effects model fitted we did not include the covariate "method".

Forest plots were created for each outcome. The potential for publication bias was assessed using funnel plots when the requirement of ten or more studies per meta-analysis was met. Egger's test to assess the funnel plots' asymmetry was applied. All analyses were conducted using STATA version 14. 


\subsection{Assessment of Risk Bias}

The assessment of methodological quality of the studies was done using checklist criteria. This systematic review included observational cohorts and cross-sectional studies, therefore, the quality assessment tool adopted from the National Institutes of Health/National Heart, Lung and Blood Institute was used (Figure S1). After answering a series of 14 questions, the quality of each study was reported as poor, fair, or good (Table S1).

\section{Results}

After applying our search criteria, 169 studies were identified, which were reduced to 152 after removing duplicates. After title-abstract screening and full manuscript review, 22 studies [29-45,49-54] met all the inclusion and exclusion criteria. Figure 1 presents the selection of the studies included in the literature review.

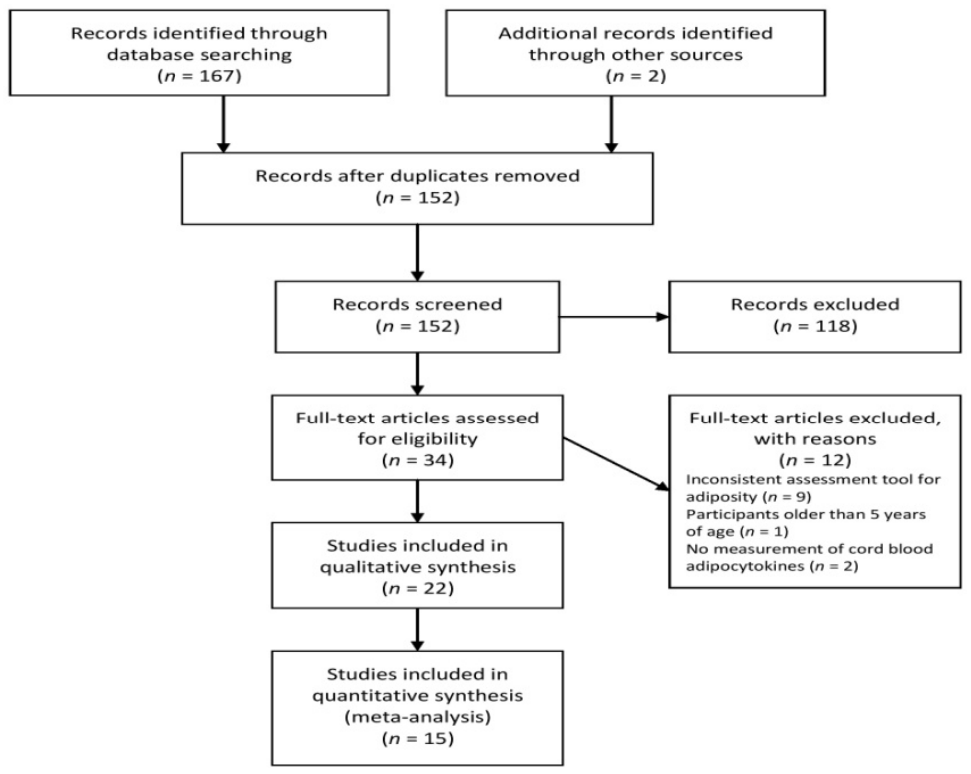

Figure 1. Flow diagram of the study.

\subsection{Characteristics}

Table 1 provides baseline characteristics of the studies included. Most of the studies examined White European neonates, while one study [49] examined an African American population. Three studies $[32,33,37]$ included neonates of more than one ethnicity. In terms of maternal characteristics and risk factors, most of the studies included mothers without diabetes or other metabolic disorders. Two studies $[30,34]$ reported the association between adipocytokines and neonatal adiposity based on intrauterine growth (SGA vs. AGA, AGA vs. LGA). 
Table 1. Characteristics of the studies included.

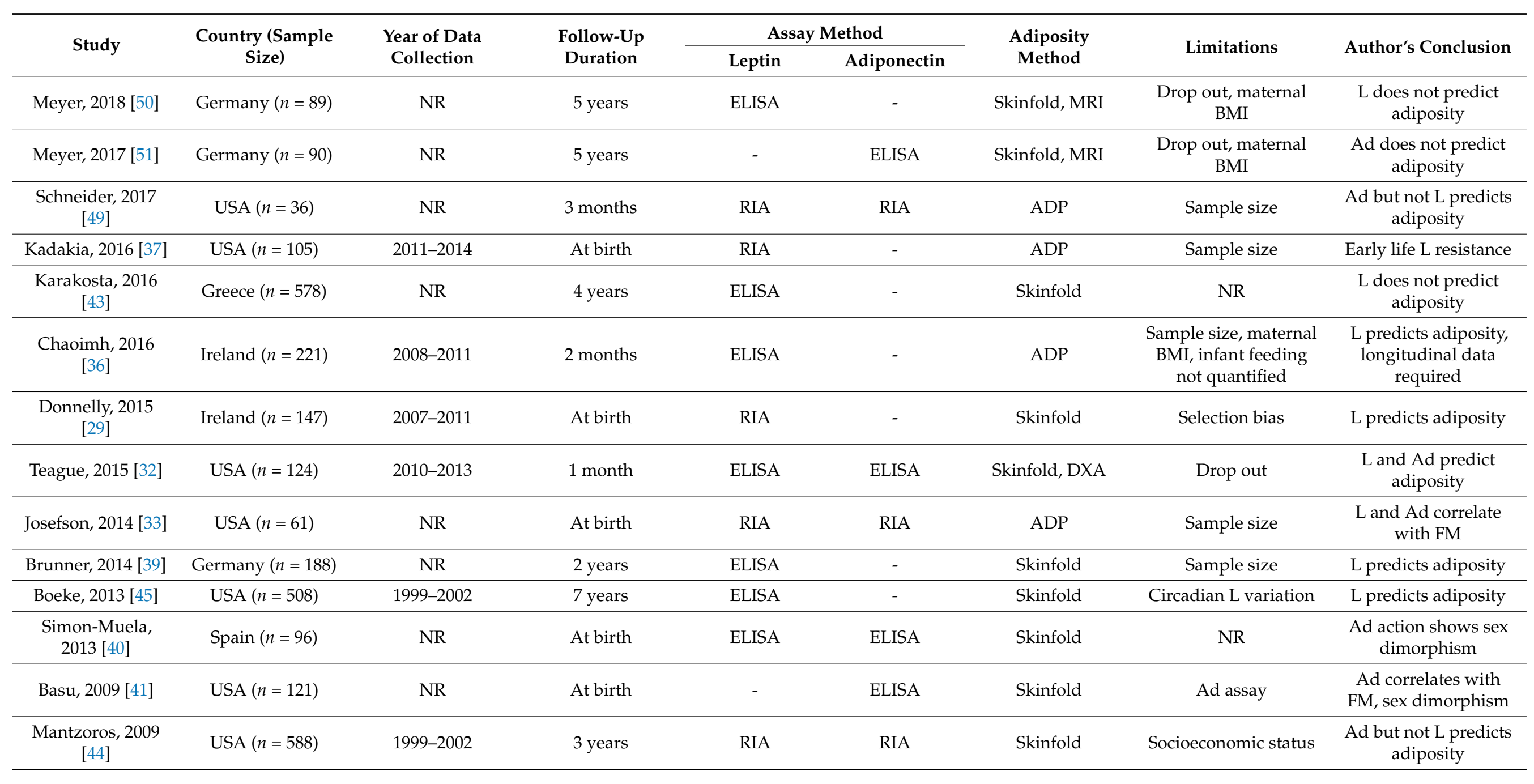


Table 1. Cont.

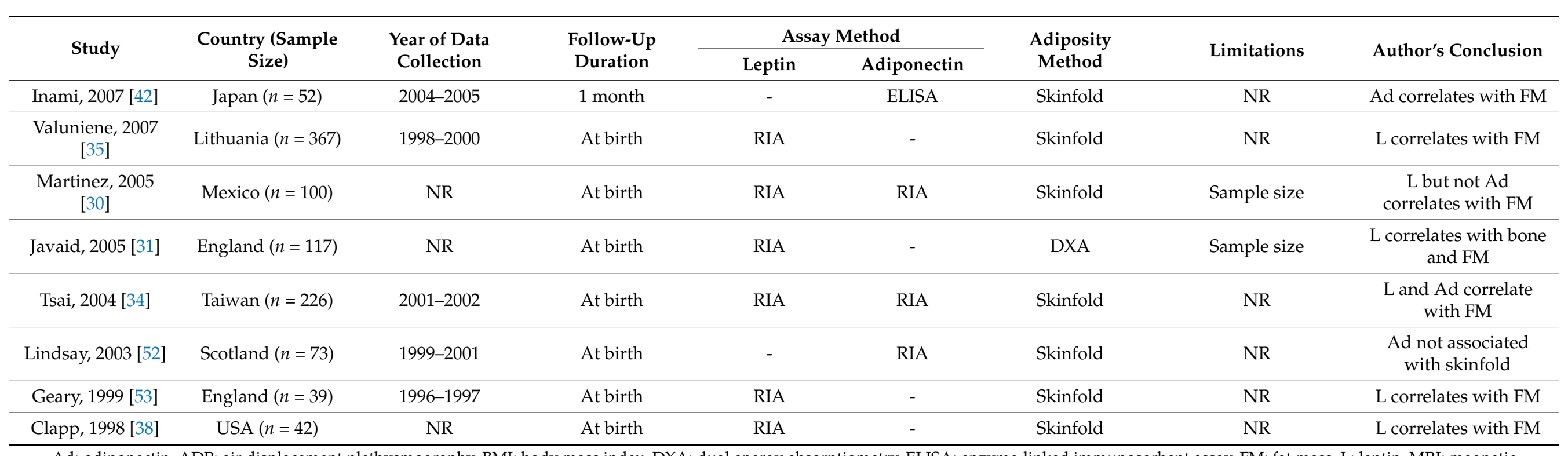

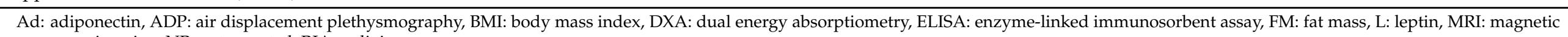
Ad: adiponectin, ADP: air displacement plethysmography, BMI:
resonance imaging, NR: not reported, RIA: radioimmunoassay. 


\subsection{Studies Reporting Leptin}

The correlation between leptin and adiposity was investigated in 17 studies [29-39,43-45,49,50,53]. Eleven [29-39] examined the relationship at birth using either Pearson correlation or multiple regression analysis. Eight $[32,36,39,43-45,49,50]$ assessed the relationship between cord blood leptin and adiposity at different time points ( 3 weeks, 2 months, 2-5 years of age) using partial correlation or multiple regression models. Eleven studies [29-31,33-35,37,38,44,49,53] used radioimmunoassay (RIA) as the method of measuring cord blood leptin, whereas six $[32,36,39,43,45,50]$ used enzyme-linked immunosorbent assay (ELISA). Body composition was assessed using DXA $(n=1)$ [31], ADP $(n=4)$ [33,36,37,49], MRI $(n=1)$ [50], or skinfold thickness $(n=12)[29,30,32,34,35,38,39,43-45,50,53]$. Total body fat mass was derived by measuring skinfold thickness at two (triceps (TR) and subscapular (SS) $[29,38,43-45]$ ), three (TR + SS + quadriceps (QD) [35]), four (TR + SS + QD + suprailiac (SI) $[30,32,39])$, or six (TR + SS + QD + SI + biceps + gastrocnemius $[34,50])$ sites.

\subsection{Studies Reporting Adiponectin}

The correlation coefficient between adiponectin and adiposity at birth was examined in eight studies [30,32-34,40-42,51]. Martinez-Cordero et al. [30] described no association between cord blood adiponectin and adiposity. For the purpose of statistical analysis, this was considered as $r=0$. Basu et al. [41] reported different correlation coefficients between male and female participants. Four studies [32,44,49,50] looked at the association between cord adiponectin and body composition at different age groups (1-3 months, $3-5$ years of age). Adiponectin was measured using either RIA $(n=6)[30,33,34,44,49,52]$ or ELISA $(n=5)$ [32,40-42,51]. To calculate body composition, two studies used ADP [33,49], one MRI [51], and the remaining used skinfold thickness at different sites: 2 sites $(n=2)$ [44,51], 4 sites $(n=5)[30,32,40,42]$, or 6 sites $(n=1)$ [34].

Two studies [52,53] reporting the association between cord plasma adipocytokines and isolated skinfold measurements (not derived total adiposity) were excluded from further analysis.

\subsection{Leptin and Neonatal Adiposity at Birth}

All 11 studies [29-39] assessing 1653 pregnancies, revealed a moderate, positive correlation between cord blood leptin and neonatal adiposity (random effect model; $r=0.487$; 95\% CI: 0.444, 0.531; Figure 2). Eight studies reported mean levels of cord blood leptin [32-34,37,43-45,50]. Applying the continuous random effects model revealed a pooled mean value of $9.1 \mathrm{ng} / \mathrm{ml}(95 \%$ CI: 8.27, 9.95; $p<0.001)$. However, a high level of heterogeneity was present $\left(\mathrm{I}^{2}=85.76 \%, p<0.001\right)$.

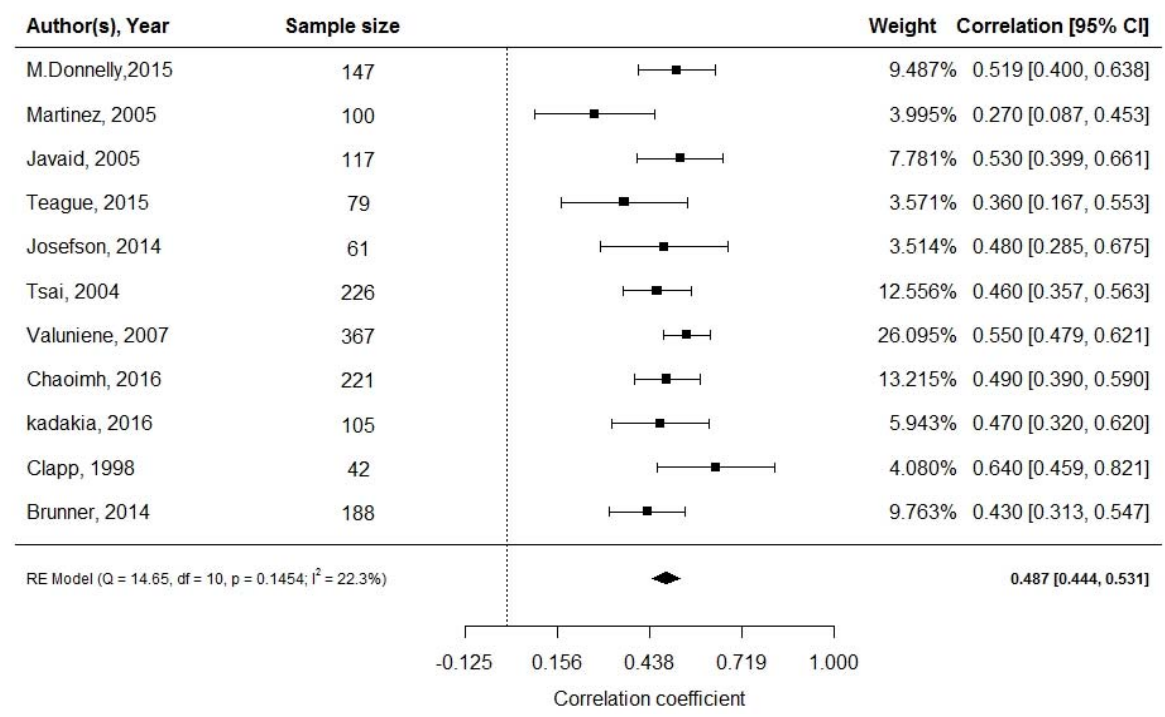

Figure 2. Cord blood leptin and fat mass at birth; df: degree of freedom, RE: random effects model. 


\subsection{Leptin and Adiposity in Early Childhood}

Eight studies reported the correlation between cord blood leptin and adiposity in early childhood at varying times [32,36,39,43-45,49,50]. Meta-analysis was not possible due to the varying times of follow-up, nature of reporting of adiposity (absolute vs. change in skinfold/fat mass), and the adjustments for differing maternal characteristics in the studies. The study results are summarized in Table 2 .

Table 2. Cord blood leptin and adiposity in early childhood.

\begin{tabular}{|c|c|c|c|c|}
\hline Study (Sample size) & $\begin{array}{c}\text { Adiposity Measure } \\
\text { Studied }\end{array}$ & Adjustments & Results & $p$-Value \\
\hline $\begin{array}{l}\text { Schneider, } 2017 \text { [49] } \\
\qquad(n=36)\end{array}$ & $\begin{array}{l}\mathrm{FM}(\mathrm{g}) \text { at } 2 \text { weeks and } \\
\text { conditional change } \\
\text { from } 2 \text { weeks to } \\
3 \text { months }\end{array}$ & $\begin{array}{l}2 \text { weeks: gestational age, age at } \\
\text { measurement, FFM } \\
3 \text { months: above }+2 \text { weeks } \\
\text { measurement and time between } \\
\text { measurements }\end{array}$ & $\begin{array}{l}2 \text { weeks: } \\
r=0.27 \\
3 \text { months: } \\
r=-0.19\end{array}$ & $p>0.05$ \\
\hline $\begin{array}{l}\text { Chaoimh, 2016 [36] } \\
\qquad(n=221)\end{array}$ & $\begin{array}{l}\text { Conditional change to } \\
\text { FMI }\left(\mathrm{kg} / \mathrm{m}^{2}\right) \text { from } \\
\text { birth to } 2 \text { months }\end{array}$ & $\begin{array}{l}\text { Maternal } \\
\text { age-education-smoking, } \\
\text { maternal BMI at } 15 \text { weeks } \\
\text { gestation, family income, sex, } \\
\text { gestational age, breast feeding }\end{array}$ & $\begin{array}{l}\text { B-Coef }(95 \% \text { CI }) \text { : } \\
-0.021 \\
(-0.034,-0.007)\end{array}$ & $p=0.003$ \\
\hline $\begin{array}{l}\text { Brunner, } 2014 \text { [39] } \\
\qquad(n=90)^{\mathrm{a}}\end{array}$ & FM (g) at 2 years & $\begin{array}{l}\text { Maternal BMI, gestational } \\
\text { weight gain, pregnancy duration, } \\
\text { sex, breast feeding }\end{array}$ & $\begin{array}{c}\text { B-Coef }(95 \% \text { CI }): \\
-14.86(-29.49,-0.23)\end{array}$ & $p=0.04$ \\
\hline $\begin{array}{l}\text { Boeke, } 2013 \text { [45] } \\
\quad(n=508)^{b}\end{array}$ & $\begin{array}{c}\text { SSF }(\mathrm{mm}) \text { at } 3 \text { years } \\
\text { SSF }(\mathrm{mm}) \text { and DXA } \\
\text { derived FM }(\mathrm{kg}) \text { at } \\
7 \text { years }\end{array}$ & $\begin{array}{l}\text { Maternal age, weight gain, } \\
\text { income, education, smoking, sex, } \\
\text { ethnicity, breast feeding }\end{array}$ & $\begin{array}{c}3 \text { years B-Coef }(95 \% \\
\text { CI0: } \\
-1.4(-2.7,-0.1) \\
7 \text { years B-Coef }(95 \% \text { CI): } \\
1.1(-1.5,2.1) \text { for SSF } \\
0.3(-0.7,1.3) \text { for DXA }\end{array}$ & $\begin{array}{l}p<0.05 \\
p>0.05\end{array}$ \\
\hline $\begin{array}{l}\text { Mantzoros, } 2009[44](n \\
=588)^{\mathrm{b}}\end{array}$ & $\begin{array}{c}\mathrm{SS}+\mathrm{TR}(\mathrm{mm}) \text { and } \\
\mathrm{SS} / \mathrm{TR}(\mathrm{mm}) \text { at } 3 \text { years } \\
\text { of age } \\
\text { (regression per } \\
10 \mathrm{ng} / \mathrm{mL} \text { of leptin) }\end{array}$ & $\begin{array}{l}\text { Maternal education, } \\
\text { pre-pregnancy BMI, weight gain, } \\
\text { gestational age, paternal BMI, } \\
\text { sex, ethnicity, breast feeding }\end{array}$ & $\begin{array}{c}\text { B-Coef }(95 \% \mathrm{CI}): \\
-0.24(-0.88,0.41) \text { for } \\
\text { SS + TR } \\
-0.22(-2.61,2.17) \text { for } \\
\text { SS } / \text { TR }\end{array}$ & $\begin{array}{l}p=0.48 \\
p=0.86\end{array}$ \\
\hline $\begin{array}{l}\text { Meyer, } 2018[50] \\
\quad(n=89)^{\mathrm{a}}\end{array}$ & $\begin{array}{l}\% \text { FM at } 3 \text { and } 5 \text { years } \\
\text { VAT }\left(\mathrm{cm}^{3}\right) \text { and SAT } \\
\left(\mathrm{cm}^{3}\right) \text { at } 5 \text { years }\end{array}$ & $\begin{array}{l}\text { Maternal BMI, gestational } \\
\text { weight gain, pregnancy duration, } \\
\text { sex, breast feeding }\end{array}$ & $\begin{array}{c}\text { B-Coef }(95 \% \text { CI }) \\
\% \text { FM at } 3:-0.06 \\
(-0.13,0.01) \\
\% \text { FM at } 5:-0.09 \\
(0.17,0.00) \\
\text { VAT: } 0.26(-1.71,2.23) \\
\text { SAT: }-0.13 \\
(-9.20,8.94)\end{array}$ & $\begin{array}{l}p=0.07 \\
p=0.04 \\
p=0.78 \\
p=0.97\end{array}$ \\
\hline $\begin{array}{l}\text { Karakosta, } 2016[43] \\
\qquad(n=578)\end{array}$ & $\begin{array}{c}\text { SSF }(\mathrm{mm}) \text { at } 4 \text { years } \\
\text { of age }\end{array}$ & $\begin{array}{c}\text { Sex, birthweight, maternal age } \\
\text { and education, parity, } \\
\text { pre-pregnancy BMI, breast } \\
\text { feeding duration }\end{array}$ & $\begin{array}{l}\text { B-Coef }(95 \% \text { CI }): 0.2 \\
(-1.4,1.7)\end{array}$ & $p>0.05$ \\
\hline $\begin{array}{l}\text { Teague, } 2015 \text { [32] } \\
\quad(n=52)\end{array}$ & $\% \mathrm{FM}$ at 1 month & Diabetic status, sex, age in days & $r=0.19$ & $p=0.19$ \\
\hline
\end{tabular}

BMI: body mass index, DXA: dual energy absorptiometry, FM: fat mass, FFM: fat free mass, FMI: fat mass index, SSF: sum of skinfolds, SS: subscapular, TR: triceps, VAT: visceral adipose tissue, SAT: subcutaneous adipose tissue. ${ }^{\mathrm{a}} / \mathrm{b}$ indicates that these two studies are possibly from the same cohort with different durations of follow-up.

In a small study of African American babies $(n=36)$, no correlation between cord leptin and fat mass at 2 weeks and 3 months of life was observed [49]. However, in 221 babies studied by Chaoimh et al., cord blood leptin was inversely associated with fat mass index at 2 months of age ( $\beta$ : $-0.021,95 \%$ CI: $-0.034,-0.007, p=0.003$ ) [36]. Similarly, 
two other studies ( $n=188$ and 508) [39,45] demonstrated an inverse correlation between cord leptin and fat mass at 2 years and sum of skinfolds (SSF) thickness at 3 years of age after adjusting for maternal and offspring characteristics. In concordance, Mantzoros et al. [44] $(n=588)$ reported an inverse relationship with fat mass at 3 years of age, although not statistically significant ( $\beta$ : $-0.24,95 \% \mathrm{CI}:-0.88,0.41 ; p=0.48$ ). However, it is likely that this study and the one by Boeke et al. [45] are from the same cohort (Project Viva) and had opposite findings presumably due to different skin fold thicknesses and follow-up numbers used. Meyer et al. [50], following a cohort of 89 offspring, showed that cord leptin was negatively associated with total fat mass (calculated using skinfold thicknesses) at 3 and 5 years of age ( 3 years: $\beta$ : $-0.02,95 \%$ CI: $-0.04,-0.00, p=0.03 ; 5$ years: $\beta$ : $-0.03,95 \%$ CI: $-0.06,-0.00, p=0.03)$. The association was not observed when fat mass was assessed by MRI at 5 years in a subgroup of 33 children (visceral adipose tissue: $\beta: 0.26,95 \% \mathrm{CI}$ : $-1.71,2.23, p=0.78$; subcutaneous adipose tissue: $\beta$ : $-0.13,95 \%$ CI: $-9.20,8.94, p=0.97$ ). Two other studies revealed no associations with fat mass at 4 (SSF derived) and 7 years (DXA derived) of age (Table 2) [43,45].

\subsection{Adiponectin and Neonatal Adiposity at Birth}

Pooled effect of the nine studies [30,32-34,40-42,51] $(n=869)$ revealed a weak positive correlation between cord blood adiponectin and neonatal fat mass (random effects model; $r=0.201 ; 95 \%$ CI: 0.125, 0.277; Figure 3). Four studies $(n=450)$ reported mean adiponectin levels with a pooled mean adiponectin at birth of $25.6 \mu \mathrm{g} / \mathrm{mL}$ (95\% CI: 16.5, 24.76). Again, a high level of heterogeneity was observed (I2 $=99.77 \%, p<0.001)[33,34,51,52]$.

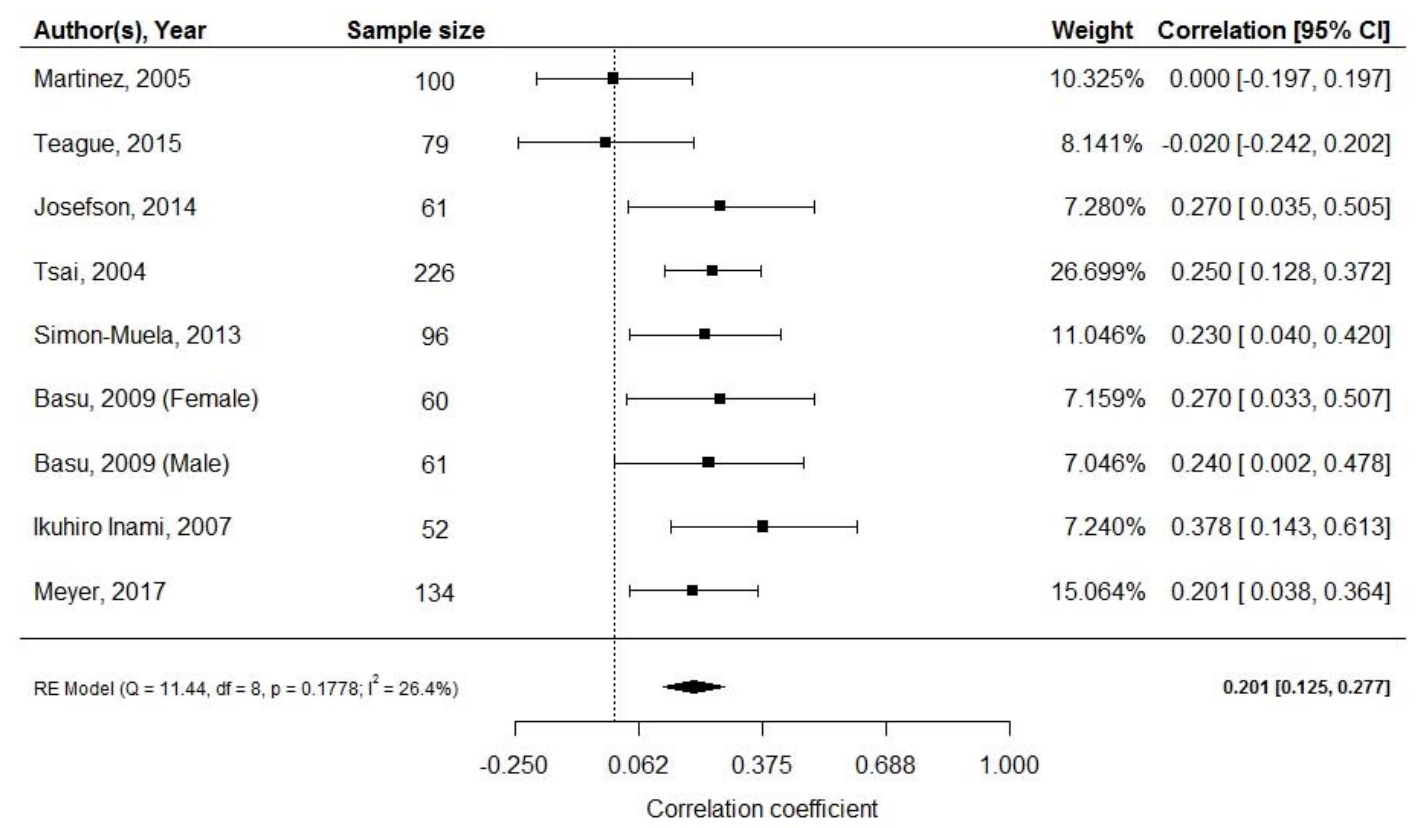

Figure 3. Cord blood adiponectin and fat mass at birth; df: degree of freedom, RE: random effects model.

\subsection{Adiponectin and Adiposity in Early Childhood}

The studies included presented mixed results regarding the relationship of cord blood adiponectin with weight gain and adiposity in different age groups. Meta-analysis was not possible, and the study results are summarized in Table 3. Teague et al. [32] $(n=52)$, showed a positive correlation of high molecular weight adiponectin (HMWA) with both weight gain $(r=0.40, p=0.003)$ and adiposity $(r=0.32, p=0.02)$ at 1 month of age. In contrast, cord adiponectin negatively predicted adiposity $(r=-0.38, p<0.05)$ in 36 African American infants at 3 months of age [49]. 
Table 3. Cord blood adiponectin and adiposity in early childhood.

\begin{tabular}{|c|c|c|c|c|}
\hline Study (Sample Size) & $\begin{array}{c}\text { Adiposity Measure } \\
\text { Studied }\end{array}$ & Adjustments & Results & $p$-Value \\
\hline $\begin{array}{l}\text { Teague, } 2015[32] \\
\quad(n=52)\end{array}$ & $\%$ FM at 1 month & $\begin{array}{l}\text { Diabetic status, sex, age } \\
\text { in days }\end{array}$ & $r=0.32$ & $p=0.02$ \\
\hline $\begin{array}{l}\text { Schneider, } 2017 \text { [49] } \\
\qquad(n=36)\end{array}$ & $\begin{array}{l}\text { FM }(g) \text { at } 2 \text { weeks and } \\
\text { conditional change from } \\
2 \text { weeks to } 3 \text { months }\end{array}$ & $\begin{array}{c}2 \text { weeks: gestational age, } \\
\text { age at measurement, FFM } \\
3 \text { months: above }+2 \text { weeks } \\
\text { measurement and time } \\
\text { between measurements }\end{array}$ & $\begin{array}{l}2 \text { weeks: } \\
r=0.45 \\
3 \text { months: } \\
r=-0.38\end{array}$ & $\begin{array}{c}p<0.001 \\
p<0.05\end{array}$ \\
\hline $\begin{array}{l}\text { Mantzoros, } 2009[44] \\
\quad(n=588)\end{array}$ & $\begin{array}{l}\mathrm{SS}+\mathrm{TR}(\mathrm{mm}) \text { and SS } / \mathrm{TR} \\
(\mathrm{mm}) \text { at } 3 \text { years of age } \\
\text { (regression per } 10 \mu \mathrm{g} / \mathrm{mL} \\
\text { of adiponectin) }\end{array}$ & $\begin{array}{c}\text { Maternal education, } \\
\text { pre-pregnancy BMI, weight } \\
\text { gain, gestational age, } \\
\text { paternal BMI, sex, ethnicity, } \\
\text { breast feeding }\end{array}$ & $\begin{array}{c}\text { B-Coef }(95 \% \text { CI }): \\
0.42(-0.11,0.95) \text { for SS + TR } \\
2.01(0.09,3.93) \text { for SS/TR }\end{array}$ & $\begin{array}{l}p=0.12 \\
p=0.04\end{array}$ \\
\hline $\begin{array}{l}\text { Meyer, } 2017 \text { [51] } \\
\quad(n=90)\end{array}$ & $\begin{array}{c}\% \mathrm{FM} \text { at } 3 \text { and } 5 \text { years } \\
\text { VAT }\left(\mathrm{cm}^{3}\right) \text { and SAT }\left(\mathrm{cm}^{3}\right) \\
\text { at } 5 \text { years }\end{array}$ & $\begin{array}{l}\text { Maternal BMI, gestational } \\
\text { weight gain, pregnancy } \\
\text { duration, sex, breast } \\
\text { feeding }\end{array}$ & $\begin{array}{c}\text { B-Coef }(95 \% \text { CI }) \\
\text { \% FM at 3: } 0.21(0.06,0.35 \\
\text { \% FM at 5: } 0.08(-0.10,0.27) \\
\text { VAT: } 1.57(-2.20,5.34) \\
\text { SAT: } 7.22(-10.17,24.62)\end{array}$ & $\begin{array}{l}p<0.05 \\
p=0.36 \\
p=0.39 \\
p=0.40\end{array}$ \\
\hline
\end{tabular}

BMI: body mass index, FM: fat mass, FFM: fat free mass, SS: subscapular, TR: triceps, VAT: visceral adipose tissue, SAT: subcutaneous adipose tissue.

Mantzoros et al. [44] $(n=588)$ showed that cord blood adiponectin was not associated with total fat mass (SS + TR thickness) at 6 months ( $\beta: 0.42,95 \%$ CI: $-0.11,0.95, p=0.12$ ) but positively with central adiposity (SS/TR thickness) at 3 years of age ( $\beta: 2.01,95 \% \mathrm{CI}$ : $0.09,3.93, p=0.04)$. Similarly, Meyer et al. [51], examining both total and HMWA, noted a positive association with $\%$ fat mass at 3 years of age ( $\beta$ : $0.04,95 \%$ CI: $0.00,0.08, p=0.04$ ) but not at 5 years ( $\beta$ : $0.02,95 \%$ CI: $-0.04,0.08, p=0.5$; Table 3 ).

\subsection{Publication Bias}

Publication bias was assessed via a funnel plot only for the leptin group, as the minimum requirement for ten studies per meta-analysis was not met in the adiponectin group. Application of the Egger's test did not reveal any asymmetry of the funnel plot, indicating no evidence of publication bias (Figure 4). 


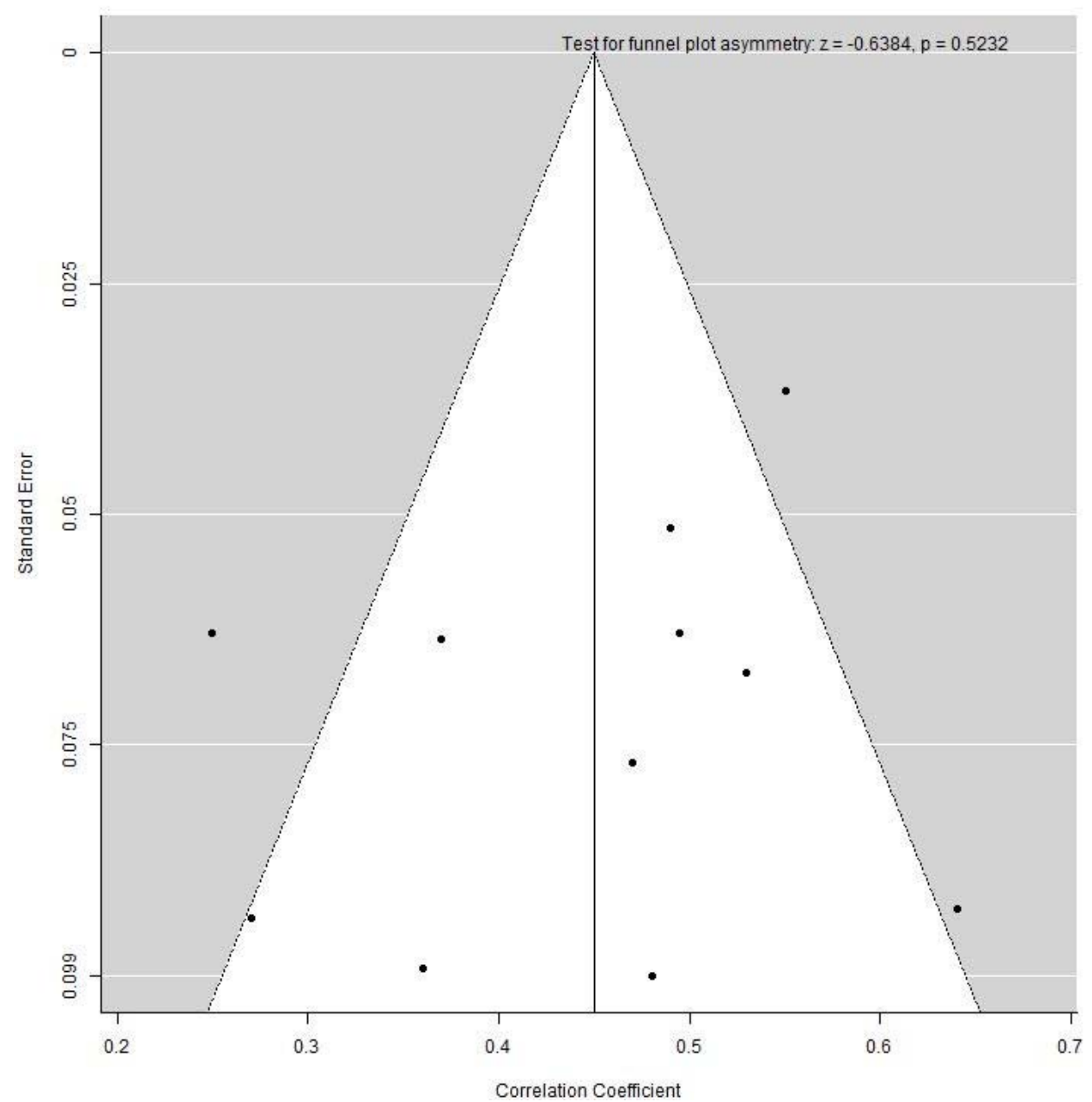

Figure 4. Funnel plot examining heterogeneity in the cord blood leptin and fat mass at birth group.

\section{Discussion}

We observed three key findings in this systematic review and meta-analysis. First, cord leptin and adiponectin levels were positively associated with adiposity at birth. The association was stronger for leptin than for adiponectin. Second, the association between leptin with adiposity was inverse in early childhood. Third, adiponectin appears to be positively associated with adiposity in early childhood, although the data for this are limited.

\subsection{Leptin and Adiposity}

Maternal leptin cannot cross the placenta due to its high molecular weight, and it is not related to cord blood levels [20]. Cord leptin is primarily derived from fetal adipose tissue although it can also come from the placenta. While the majority of placental leptin drains into the maternal circulation, small amounts enter the fetal circulation [54]. Leptin levels are higher in the umbilical artery compared to that in the umbilical vein [55]. Fetal leptin is detectable at as early as 18 weeks of gestation, with levels rising as pregnancy progresses, in concordance with fetal fat accumulation [56]. In addition, the presence of leptin mRNA and leptin receptors in various fetal tissues implies its role as a growth factor during intrauterine development. All these findings support that cord leptin is a good marker of adiposity at birth.

Our analysis revealed that cord leptin levels are inversely related to adiposity at 3 years of age $[39,44,45,50]$, but this was not seen at 4 and 7 years [43,45]. Chaoimh et al. [36] noted that cord leptin is inversely associated with adiposity gain from birth to 2 months of age, by an objective adiposity measure, ADP. In our study, pooled mean leptin level at birth 
was $9.1 \mathrm{ng} / \mathrm{mL}(n=2242)$. Although, there is no reference range for cord blood leptin levels, Karakosta et al. [57] observed a mean leptin value of $7.7 \mathrm{ng} / \mathrm{mL}$ in a cohort of 398 healthy, full term neonates born in Greece. Taken together, it appears that children born with higher leptin levels, develop a "compensatory behavior" driven by the anorexigenic effect of leptin in early postnatal life, which lasts up to 3 years of age. In order to maintain a positive energy balance and enhance vital organ development, leptin's full metabolic effect is not exerted before the second postnatal week [58]. The above observation could potentially explain the positive association between cord leptin and adiposity during the first weeks of life, as described by Schneider et al. [49] and Teague et al. [32].

The above conclusion is also supported by evidence from animal studies. Leptin plays an important role in brain development. The human hypothalamus develops predominantly during the prenatal period [59]. The arcuate nucleus (ARC), the major site for energy regulation, develops after 34 weeks of gestation, but further changes take place in the early postnatal life. Independent of fat mass accretion, a leptin surge happens in the immediate postnatal period, which is critical for the development of projections from the ARC to paraventricular hypothalamic nuclei [60]. Ob/ob mice have impaired projections, an effect which can be reversed by early life leptin administration, whereas leptin administration in adulthood has no effect, implying a tight window for leptin's neurotrophic action [61].

Thus, raised leptin levels at birth may adversely program the hypothalamus (via an impaired leptin surge), with effects becoming evident after the third year of life. The initial inverse correlation between cord leptin and adiposity may be due to the anorexigenic effect of leptin, followed by leptin resistance, resulting in hyperphagia and increased adiposity. In the present systematic review, Meyer et al. [50] and Boeke et al. [45] used direct measures of adiposity (MRI, DXA) to assess the association between cord leptin and adiposity beyond the third year of life. Both studies demonstrated a trend for cord leptin to inversely predict adiposity at 3 years of life, which was converted to a positive association by the ages of 5 and 7 . Boeke et al. [45] also highlighted that serum leptin at 3 years of age positively predicts adiposity at 7 years of age, results consistent with leptin resistance.

\subsection{Adiponectin and Adiposity}

Adiponectin levels increase by 20-fold from midgestation to term [62]. Cord levels are not related to maternal adiponectin $[24,63]$ and placental production is not yet confirmed [25,64]. Sivan et al. [27] showed that cord blood adiponectin levels were similar to those four days postpartum, confirming independent fetal production. The inverse correlation between adipose tissue and adiponectin observed in the adult population is not present during the early stages of life. Evidence suggests that the shift from positive to negative correlation between adiponectin and fat mass occurs around school-entry age [65]. Multiple sites of adiponectin expression other than adipose tissue during fetal life [28], such as brown adipose tissue [66], the subcutaneous-to-visceral fat ratio of neonates [67], and the inhibition of adiponectin expression from inflammatory cytokines produced by hypertrophic adult adipocytes [68] could potentially explain the different metabolic profile between neonatal and adult life.

The predictive capacity of cord adiponectin for the development of future adiposity remains unclear. Small sample size, different methods to measure adiponectin (ELISA, RIA), and different multimeric forms examined may contribute to the inconsistent results. Simpson et al. [69] recently reviewed the association between adiponectin and adiposity at 9 and 17 years of age. Results showed no correlation with adiposity at 9 years and a positive correlation at 17 years with a very small effect size ( $\beta: 0.02,95 \%$ CI: $0.00,0.03, p<0.05$ ). Major limitations of the study were the big loss to follow-up and the small percentage of children with obesity (sample not representative of most populations), which could have potentially attenuated any associations. 


\subsection{Strengths and Weakness}

To our knowledge, our systematic review and meta-analysis is the first to assess the correlation of cord blood adipocytokines with adiposity at different time points. However, while it had reasonable sample size to assess the independent associations of leptin and adiponectin with adiposity at birth, it did not have adequate sample size for early childhood. In addition, as this review included observational cohorts and cross sectional studies, these associations do not prove causality. We also acknowledge that in the majority of the studies fat mass was derived from the sum of skinfolds and not by direct measures of adiposity, which would have minimized intra- and inter-subject variability. Studies investigating the relationship between ELISA- and RIA-based methods are rare, therefore, the assays used to measure adipocytokines may have contributed to the variability of the results. Finally, studies adjusted their results for different confounding variables. Maternal body mass index (BMI) was considered in all studies, whereas only half of the included studies $[29,36,37,40,43-45,49,53]$ controlled for smoking during pregnancy, a factor inversely related to cord blood adipocytokines as well as birth size.

\section{Conclusions}

The present systematic review and meta-analysis reveals positive associations between cord blood leptin, adiponectin, and body fat at birth. However, cord blood leptin inversely predicts adiposity in early childhood, around 3 years of age, suggesting the early development of leptin resistance, although data for this are limited. In order to understand the origins of obesity and metabolic diseases, we need to investigate the trajectory of body composition (not just by weight) in early childhood and its relationship with key metabolic factors. Body weight, BMI, and skinfold measurements do not reflect fat mass (FM) precisely and are prone to inter- and intra-observer variation. However, objective measures of adiposity are cumbersome and not widely available. Biochemical markers in cord blood such as leptin are easy to measure and are potentially useful for risk stratification of children at birth for obesity and other related cardiometabolic disorders in later life. This could help in targeted, individualized prevention strategies to be implemented from birth/early childhood. Additional studies on the long-term effects of leptin and adiponectin at birth are required to confirm our findings on the predictive value on future adverse cardiometabolic risk and to understand the potential underlying mechanisms.

Supplementary Materials: The following are available online at https:/ / www.mdpi.com/1660-460 1/18/4/1897/s1 [70]. Figure S1. NIH quality assessment tool; Table S1. Studies were assessed using the NIH quality assessment tool for observational cohort and cross sectional studies.

Author Contributions: O.O. and P.S. conceived the study and prepared the study methodology. C.B. and N.S. conducted the literature review, data extraction, and critical analysis. Y.W. supervised the formal analysis and interpretation of data. O.O. and P.S. supervised data extraction, statistical analysis, interpretation of the results. O.O. and P.S. acted as the third reviewer in case of disagreement between the two independent reviewers (C.B. and N.S.) during data extraction. C.B. was responsible for the writing and preparation of the original draft. All authors participated in the original manuscript preparation and editing. O.O. and P.S. supervised the original manuscript preparation. All authors have read and agreed to the published version of the manuscript.

Funding: This research received no external funding.

Institutional Review Board Statement: Ethical review and approval were waived for this study, as the review involved synthesis of published data. The individual studies included obtained approval from the respective local research ethics committee. Studies without ethics committee approval were not included in the present systematic review.

Informed Consent Statement: Not applicable.

Data Availability Statement: The data presented in this study are available on request from the corresponding author. The data are not publicly available due to the standard operating procedures of the corresponding author's institutional policy for systematic review and meta-analysis. 
Acknowledgments: The authors would like to thank library services at George Eliot Hospital, Nuneaton, UK, for their help in retrieving original articles included in this systematic review.

Conflicts of Interest: The authors have no conflict of interest to report.

\section{References}

1. World Health Organization. Report of the commission on ending childhood obesity; World Health Organization: Geneva, Switzerland, 2016.

2. Simmonds, M.; Llewellyn, A.; Owen, C.G.; Woolacott, N. Predicting adult obesity from childhood obesity: A systematic review and meta-analysis. Obes. Rev. 2016, 17, 95-107. [CrossRef]

3. Tirosh, A.; Shai, I.; Afek, A.; Dubnov-Raz, G.; Ayalon, N.; Gordon, B.; Derazne, E.; Tzur, D.; Shamis, A.; Vinker, S.; et al. Adolescent BMI trajectory and risk of diabetes versus coronary disease. N. Engl. J. Med. 2011, 364, 1315-1325. [CrossRef] [PubMed]

4. Franks, P.W.; Hanson, R.L.; Knowler, W.C.; Sievers, M.L.; Bennett, P.H.; Looker, H.C. Childhood obesity, other cardiovascular risk factors, and premature death. N. Engl. J. Med. 2010, 362, 485-493. [CrossRef] [PubMed]

5. Lauby-Secretan, B.; Scoccianti, C.; Loomis, D.; Grosse, Y.; Bianchini, F.; Straif, K. Body fatness and cancer-Viewpoint of the IARC Working Group. N. Engl. J. Med. 2016, 375, 794-798. [CrossRef] [PubMed]

6. Sahoo, K.; Sahoo, B.; Choudhury, A.K.; Sofi, N.Y.; Kumar, R.; Bhadoria, A.S. Childhood obesity: Causes and consequences. In. J. Family Med. Prim. Care 2015, 4, 187-192.

7. Barker, D.J.P.; Godfrey, K.M.; Gluckman, P.D.; Harding, J.E.; Owens, J.A.; Robinson, J.S. Fetal nutrition and cardiovascular disease in adult life. Lancet 1993, 341, 938-941. [CrossRef]

8. Kuzawa, C.W. Adipose tissue in human infancy and childhood: An evolutionary perspective. Am. J. Phys. Anthropol. 1998, 107, 177-209. [CrossRef]

9. Pelletier, D.L.; Frongillo Jr, E.A.; Habicht, J.-P. Epidemiologic evidence for a potentiating effect of malnutrition on child mortality. Am. J. Public Health 1993, 83, 1130-1133. [CrossRef]

10. Victora, C.G.; Barros, F.C.; Kirkwood, B.R.; Vaughan, J.P. Pneumonia, diarrhea, and growth in the first 4 y of life: A longitudinal study of 5914 urban Brazilian children. Am. J. Clin. Nutr. 1990, 52, 391-396. [CrossRef]

11. WHO. Physical status: The use and interpretation of anthropometry. World Health Organization: Geneva, Switzerland, 2013.

12. Wells, J.C.K. Toward Body Composition Reference Data for Infants, Children, and Adolescents. Adv. Nutr. 2014, 5, 320S-329S. [CrossRef]

13. Friedman, J. 20 years of leptin: Leptin at 20: An overview. J. Endocrinol. 2014, 223, T1-T8. [CrossRef]

14. Hassink, S.G.; de Lancey, E.; Sheslow, D.V.; Smith-Kirwin, S.M.; O'Connor, D.M.; Considine, R.V.; Opentanova, I.; Dostal, K.; Spear, M.L.; Leef, K.; et al. Placental leptin: An important new growth factor in intrauterine and neonatal development? Pediatrics 1997, 100, E1. [CrossRef]

15. Wang, J.; Liu, R.; Hawkins, M.; Barzilai, N.; Rossetti, L. A nutrient-sensing pathway regulates leptin gene expression in muscle and fat. Nature 1998, 393, 684. [CrossRef]

16. Laharrague, P.; Larrouy, D.; Fontanilles, A.M.; Truel, N.; Campfield, A.; Tenenbaum, R.; Galitzky, J.; Corberand, J.X.; Penicaud, L.; Casteilla, L.; et al. High expression of leptin by human bone marrow adipocytes in primary culture. FASEB J. 1998, 12, 747-752. [CrossRef] [PubMed]

17. Bado, A.; Levasseur, S.; Attoub, S.; Kermorgant, S.; Laigneau, J.P.; Bortoluzzi, M.N.; Moizo, L.; Lehy, T.; Guerre-Milllo, M.; Le Marchand-Brustel, Y.; et al. The stomach is a source of leptin. Nature 1998, 394, 790. [CrossRef] [PubMed]

18. Chan, J.L.; Heist, K.; DePaoli, A.M.; Veldhuis, J.D.; Mantzoros, C.S. The role of falling leptin levels in the neuroendocrine and metabolic adaptation to short-term starvation in healthy men. J. Clin. Investig. 2003, 111, 1409-1421. [CrossRef] [PubMed]

19. Tartaglia, L.A.; Dembski, M.; Weng, X.; Deng, N.; Culpepper, J.; Devos, R.; Richards, G.J.; Campfield, L.A.; Clark, F.T.; Deeds, J.; et al. Identification and expression cloning of a leptin receptor, OB-R. Cell 1995, 83, 1263-1271. [CrossRef]

20. Alexe, D.-M.; Syridou, G.; Petridou, E.T. Determinants of early life leptin levels and later life degenerative outcomes. Clin. Med. Res. 2006, 4, 326-335. [CrossRef]

21. Brochu-Gaudreau, K.; Rehfeldt, C.; Blouin, R.; Bordignon, V.; Murphy, B.D.; Palin, M.-F. Adiponectin action from head to toe. Endocrine 2010, 37, 11-32. [CrossRef] [PubMed]

22. Hu, E.; Liang, P.; Spiegelman, B.M. AdipoQ is a novel adipose-specific gene dysregulated in obesity. J. Biol. Chem. 1996, 271, 10697-10703. [CrossRef] [PubMed]

23. Weyer, C.; Funahashi, T.; Tanaka, S.; Hotta, K.; Matsuzawa, Y.; Pratley, R.E.; Tataranni, P.A. Hypoadiponectinemia in obesity and type 2 diabetes: Close association with insulin resistance and hyperinsulinemia. J. Clin. Endocrinol. Metab. 2001, 86, 1930-1935. [CrossRef]

24. Chan, T.-F.; Yuan, S.-S.F.; Chen, H.-S.; Guu, C.-F.; Wu, L.-C.; Yeh, Y.-T.; Chung, Y.-F.; Jong, S.-B.; Su, J.-H. Correlations between umbilical and maternal serum adiponectin levels and neonatal birthweights. Acta Obstet. Gynecol. Scand. 2004, 83, 165-169. [CrossRef]

25. McDonald, E.A.; Wolfe, M.W. Adiponectin attenuation of endocrine function within human term trophoblast cells. Endocrinology 2009, 150, 4358-4365. [CrossRef] [PubMed]

26. Mazaki-Tovi, S.; Kanety, H.; Pariente, C.; Hemi, R.; Wiser, A.; Schiff, E.; Sivan, E. Maternal serum adiponectin levels during human pregnancy. J. Perinatol. 2007, 27, 77. [CrossRef] [PubMed] 
27. Sivan, E.; Mazaki-Tovi, S.; Pariente, C.; Efraty, Y.; Schiff, E.; Hemi, R.; Kanety, H. Adiponectin in human cord blood: Relation to fetal birth weight and gender. J. Clin. Endocrinol. Metab. 2003, 88, 5656-5660. [CrossRef] [PubMed]

28. Corbetta, S.; Bulfamante, G.; Cortelazzi, D.; Barresi, V.; Cetin, I.; Mantovani, G.; Bondioni, S.; Beck-Peccoz, P.; Spada, A. Adiponectin expression in human fetal tissues during mid-and late gestation. J. Clin. Endocrinol. Metab. 2005, 90, $2397-2402$. [CrossRef]

29. Donnelly, J.M.; Lindsay, K.L.; Walsh, J.M.; Horan, M.; Molloy, E.J.; McAuliffe, F.M. Fetal metabolic influences of neonatal anthropometry and adiposity. BMC Pediatrics 2015, 15, 175. [CrossRef] [PubMed]

30. Martinez-Cordero, C.; Amador-Licona, N.; Guizar-Mendoza, J.M.; Hernandez-Mendez, J.; Ruelas-Orozco, G. Body fat at birth and cord blood levels of insulin, adiponectin, leptin, and insulin-like growth factor-I in small-for-gestational-age infants. Arch. Med. Res. 2006, 37, 490-494. [CrossRef]

31. Javaid, M.K.; Godfrey, K.M.; Taylor, P.; Robinson, S.M.; Crozier, S.R.; Dennison, E.M.; Robinson, J.S.; Breier, B.R.; Arden, N.K.; Cooper, C. Umbilical cord leptin predicts neonatal bone mass. Calcif. Tissue Int. 2005, 76, 341-347. [CrossRef] [PubMed]

32. Teague, A.M.; Fields, D.A.; Aston, C.E.; Short, K.R.; Lyons, T.J.; Chernausek, S.D. Cord blood adipokines, neonatal anthropometrics and postnatal growth in offspring of Hispanic and Native American women with diabetes mellitus. Reprod. Biol. Endocrinol. 2015, 13, 68. [CrossRef]

33. Josefson, J.L.; Zeiss, D.M.; Rademaker, A.W.; Metzger, B.E. Maternal leptin predicts adiposity of the neonate. Horm. Res. Paediatr. 2014, 81, 13-19. [CrossRef] [PubMed]

34. Tsai, P.J.; Yu, C.H.; Hsu, S.P.; Lee, H.Y.; Chiou, C.H.; Hsu, Y.W.; Ho, S.C.; Chu, C.H. Cord plasma concentrations of adiponectin and leptin in healthy term neonates: Positive correlation with birthweight and neonatal adiposity. Clin. Endocrinol. 2004, 61, 88-93. [CrossRef] [PubMed]

35. Valuniene, M.; Verkauskiene, R.; Boguszewski, M.; Dahlgren, J.; Lasiene, D.; Lasas, L.; Albertssson Wikland, K. Leptin levels at birth and in early postnatal life in small- and appropriate-for-gestational-age infants. Medicina 2007, 43, 784-791. [CrossRef] [PubMed]

36. Chaoimh, C.N.; Murray, D.M.; Kenny, L.C.; Irvine, A.D.; Hourihane, J.O.; Kiely, M. Cord blood leptin and gains in body weight and fat mass during infancy. Eur. J. Endocrinol. 2016, 175, 403-410. [CrossRef] [PubMed]

37. Kadakia, R.; Zheng, Y.; Zhang, Z.; Zhang, W.; Hou, L.; Josefson, J.L. Maternal pre-pregnancy BMI downregulates neonatal cord blood LEP methylation. Pediatric Obes. 2017, 12, 57-64. [CrossRef]

38. Clapp Iii, J.F.; Kiess, W. Cord blood leptin reflects fetal fat mass. J. Soc. Gynecol. Investig. 1998, 5, 300-303. [CrossRef]

39. Brunner, S.; Schmid, D.; Huttinger, K.; Much, D.; Bruderl, M.; Seldmeier, E.-M.; Kratzsch, J.; Amann-Gassnerl, U.; Bader, B.; Hauner, H. Effect of reducing the n-6/n-3 fatty acid ratio on the maternal and fetal leptin axis in relation to infant body composition. Obesity 2014, 22, 217-224. [CrossRef]

40. Simon-Muela, I.; Naf, S.; Ballesteros, M.; Vendrell, J.; Ceperuelo-Mallafre, V.; De la Flor, M.; Megia, A. Gender determines the actions of adiponectin multimers on fetal growth and adiposity. Am. J. Obstet. Gynecol. 2013, 208, e481-e487. [CrossRef] [PubMed]

41. Basu, S.; Laffineuse, L.; Presley, L.; Minium, J.; Catalano, P.M.; Hauguel-De Mouzon, S. In utero gender dimorphism of adiponectin reflects insulin sensitivity and adiposity of the fetus. Obesity 2009, 17, 1144-1149. [CrossRef]

42. Inami, I.; Okada, T.; Fujita, H.; Makimoto, M.; Hosono, S.; Minato, M.; Takahashi, S.; Harada, K.; Yamamoto, T. Impact of serum adiponectin concentration on birth size and early postnatal growth. Pediatric Res. 2007, 61, 604. [CrossRef]

43. Karakosta, P.; Roumeliotaki, T.; Chalkiadaki, G.; Sarri, K.; Vassilaki, M.; Venihaki, M.; Malliaraki, N.; Kampa, M.; Castanas, E.; Kogevinas, M. Cord blood leptin levels in relation to child growth trajectories. Metabolism 2016, 65, 874-882. [CrossRef]

44. Mantzoros, C.S.; Rifas-Shiman, S.L.; Williams, C.J.; Fargnoli, J.L.; Kelesidis, T.; Gillman, M.W. Cord blood leptin and adiponectin as predictors of adiposity in children at 3 years of age: A prospective cohort study. Pediatrics 2009, 123, 682-689. [CrossRef]

45. Boeke, C.E.; Mantzoros, C.S.; Hughes, M.D.; Rifas-Shiman, S.L.; Villamor, E.; Zera, C.; Gillman, M. Differential associations of leptin with adiposity across early childhood. Obesity 2013, 21, 1430-1437. [CrossRef] [PubMed]

46. Persson, B.; Westgren, M.; Celsi, G.; Nord, E.; Ortqvist, E. Leptin concentrations in cord blood in normal newborn infants and offspring of diabetic mothers. Horm. Metab. Res. 1999, 31, 467-471. [CrossRef] [PubMed]

47. Gross, G.A.; Solenberger, T.; Philpott, T.; Holcomb, W.L.; Landt, M. Plasma leptin concentrations in newborns of diabetic and nondiabetic mothers. Am. J. Perinatol. 1998, 11, 243-247. [CrossRef] [PubMed]

48. Stroup, D.F.; Berlin, J.A.; Morton, S.C.; Olkin, I.; Williamson, G.D.; Rennie, D.; Moher, D.; Becker, B.J.; Sipe, T.A.; Thacker, S.B. Meta-analysis of observational studies in epidemiology: A proposal for reporting. Meta-analysis Of Observational Studies in Epidemiology (MOOSE) group. JAMA 2000, 283, 2008-2012. [CrossRef] [PubMed]

49. Schneider, C.R.; Catalano, P.M.; Biggio, J.R.; Gower, B.A.; Chandler-Laney, P.C. Associations of neonatal adiponectin and leptin with growth and body composition in African American infants. Pediatric Obes. 2018, 13, 485-491. [CrossRef] [PubMed]

50. Meyer, D.M.; Brei, C.; Stecher, L.; Much, D.; Brunner, S.; Hauner, H. Leptin in Maternal Plasma and Cord Blood as a Predictor of Offspring Adiposity at 5 Years: A Follow-up Study. Obesity 2018, 26, 279-283. [CrossRef] [PubMed]

51. Meyer, D.M.; Brei, C.; Stecher, L.; Much, D.; Brunner, S.; Hauner, H. Cord blood and child plasma adiponectin levels in relation to childhood obesity risk and fat distribution up to 5 y. Pediatric Res. 2017, 81, 745. [CrossRef]

52. Lindsay, R.S.; Walker, J.D.; Havel, P.J.; Hamilton, B.A.; Calder, A.A.; Johnstone, F.D. Adiponectin is present in cord blood but is unrelated to birth weight. Diabetes Care 2003, 26, 2244-2249. [CrossRef] 
53. Geary, M.; Pringle, P.J.; Persaud, M.; Wilshin, J.; Hindmarsh, P.C.; Rodeck, C.H.; Brook, C.G. Leptin concentrations in maternal serum and cord blood: Relationship to maternal anthropometry and fetal growth. BJOG Int. J. Obstet. Gynaecol. 1999, 106, 10541060. [CrossRef]

54. Linnemann, K.; Malek, A.; Sager, R.; Blum, W.F.; Schneider, H.; Fusch, C. Leptin production and release in the dually in vitro perfused human placenta. J. Clin. Endocrinol. Metab. 2000, 85, 4298-4301.

55. Schubring, C.; Kiess, W.; Englaro, P.; Rascher, W.; Dotsch, J.; Hanitsch, S.; Attanasio, A.; Blum, W.F. Levels of leptin in maternal serum, amniotic fluid, and arterial and venous cord blood: Relation to neonatal and placental weight. J. Clin. Endocrinol. Metab. 1997, 82, 1480-1483. [CrossRef] [PubMed]

56. Jaquet, D.; Leger, J.; Levy-Marchal, C.; Oury, J.F.; Czernichow, P. Ontogeny of leptin in human fetuses and newborns: Effect of intrauterine growth retardation on serum leptin concentrations. J. Clin. Endocrinol. Metab. 1998, 83, 1243-1246. [CrossRef] [PubMed]

57. Karakosta, P.; Georgiou, V.; Fthenou, E.; Margioris, A.; Castanas, E.; Kogevinas, M.; Kampa, M.; Chatzi, L. Gender-specific reference intervals for cord blood leptin in Crete, Greece. Eur. J. Pediatrics 2012, 171, 1563-1566. [CrossRef]

58. Mistry, A.M.; Swick, A.; Romsos, D.R. Leptin alters metabolic rates before acquisition of its anorectic effect in developing neonatal mice. Am. J. Physiol. Regul. Integr. Comp. Physiol. 1999, 277, R742-R747. [CrossRef]

59. Koutcherov, Y.; Mai, J.K.; Paxinos, G. Hypothalamus of the human fetus. J. Chem. Neuroanat. 2003, 26, 253-270. [CrossRef]

60. Bouret, S.G.; Draper, S.J.; Simerly, R.B. Formation of projection pathways from the arcuate nucleus of the hypothalamus to hypothalamic regions implicated in the neural control of feeding behavior in mice. J. Neurosci. 2004, 24, 2797-2805. [CrossRef] [PubMed]

61. Bouret, S.G.; Draper, S.J.; Simerly, R.B. Trophic action of leptin on hypothalamic neurons that regulate feeding. Science 2004, 304, 108-110. [CrossRef] [PubMed]

62. Kajantie, E.; Hytinantti, T.; Hovi, P.; Andersson, S. Cord plasma adiponectin: A 20-fold rise between 24 weeks gestation and term. J. Clin. Endocrinol. Metab. 2004, 89, 4031-4036. [CrossRef]

63. Weyermann, M.; Beermann, C.; Brenner, H.; Rothenbacher, D. Adiponectin and leptin in maternal serum, cord blood, and breast milk. Clin. Chem. 2006, 52, 2095-2102. [CrossRef]

64. Wang, Y.; Lu, G.; Wong, W.P.S.; Vliegenthart, J.F.G.; Gerwig, G.J.; Lam, K.S.L.; Cooper, G.J.S.; Xu, A. Proteomic and functional characterization of endogenous adiponectin purified from fetal bovine serum. Proteomics 2004, 4, 3933-3942. [CrossRef] [PubMed]

65. Asayama, K.; Hayashibe, H.; Dobashi, K.; Uchida, N.; Nakane, T.; Kodera, K.; Shirahata, A.; Taniyama, M. Decrease in serum adiponectin level due to obesity and visceral fat accumulation in children. Obes. Res. 2003, 11, 1072-1079. [CrossRef] [PubMed]

66. Viengchareun, S.; Zennaro, M.-C.; Pascual-Le Tallec, L.; Lombes, M. Brown adipocytes are novel sites of expression and regulation of adiponectin and resistin. FEBS Lett. 2002, 532, 345-350. [CrossRef]

67. Milan, G.; Granzotto, M.; Scarda, A.; Calcagno, A.; Pagano, C.; Federspil, G.; Vettor, R. Resistin and adiponectin expression in visceral fat of obese rats: Effect of weight loss. Obes. Res. 2002, 10, 1095-1103. [CrossRef]

68. Kamon, J.; Yamauchi, T.; Waki, H.; Uchika, S.; Ito, Y.; Suzuki, R.; Aoyama, M.; Takasawa, T.; Kubota, N.; Terauchi, Y.; et al. Mechanism for the regulation of adiponectin expression. Diabetes 2002, 51, A87.

69. Simpson, J.; Smith, A.D.; Fraser, A.; Sattar, N.; Lindsay, R.S.; Ring, S.M.; Tilling, K.; Smith, G.D.; Lawlor, D.; Nelson, S.M. Programming of Adiposity in Childhood and Adolescence: Associations with Birth Weight and Cord Blood Adipokines. J. Clin. Endocrinol. Metab. 2017, 102, 499-506. [CrossRef]

70. National Heart, Lung and Blood Institute Home Page. Available online: http://www.nhlbi.nih.gov/health-topics/study-qualityassessment-tools (accessed on 12 February 2021). 